Journal of Jungian Scholarly Studies

Vol. 7, No. 3, 2011

\title{
Symbols of Transformation, Phenomenology, and Magic Mountain
}

\author{
Gary Brown, Ph.D.
}

\section{On Volume I}

In celebrating the centennial of Carl Jung's Wandlungen und Symbole der Libido, which was published in 1911-12, we must note the book's complex history. Not only did the book set in motion his complicated break from Freud, who finally in 1913 wrote to Jung: "Take your full freedom and spare me your supposed "tokens of friendship" (Bair 238), but having traced in it the mythical fantasies of a liberated American woman named Miss Frank Miller, whose case study had been published by the Swiss psychiatrist Théodore Flournoy, Jung realized that unlike Miss Miller, he was unaware of the myths he might be living in his own life. Since he had argued that only mythical imagos (his original term for archetypes) could release one from the domain of instinct, there had to be myths of which he was ignorant operating in his own development. It was especially important for him to learn these since he had argued that Miss Miller was headed for a schizophrenic breakdown without increased awareness of her mythic processes. Yet she was ahead of him. His awareness of this deficiency sparked his return to journaling, which, as John Beebe has pointed out in "The Red Book as a Work of Conscience, " Jung had abandoned for over a decade while focusing on his worldly accomplishments. This return to journaling yielded the famous, recently published Red Book. Jung attributes his increased understanding of the stages of psychic processes to his practice of active imagination in this journal. Hence, Wandlungen und Symbole der Libido not only laid the theoretical foundation for the explorations of the Red Book but also initiated its processes of introversion in Jung, for, as Jung realized and admitted by 1925 , that book was already as much autobiographical as it was about Miss Miller (Analytical Psychology 27). In 1952, Jung decided to carry out a massive revision of the original Wandlungen und Symbole der Libido for the fourth edition. Since Freud was now dead, Jung could describe more openly in a new introduction his differences with Freud that had made the book, and thereby the inevitable break, necessary. In carrying out this revision, Jung introduced into the original text a new array of terms that he had developed subsequently in his effort to understand his own process of psychic transformation announced and experienced in the original edition and the subsequent Red Book. Retranslated into English as Symbols of Transformation (1956), the fourth edition includes not only the original insights prior to the Red Book but also those developments derived from the Red Book over the more than forty subsequent years. As a small measure of Jung's accomplishments during this period, we note 
some of the terms introduced into Symbols of Transformation that were missing from the first incarnation of Psychology of the Unconscious. These include archetypes, anima, animus, types, the collective unconscious, individuation, coniunctio, anything alchemical, self, the transcendent function, the numinous, primordial image, and wholeness. Even the word "psyche" appears for the first time by itself as an image of totality rather than merely as psychic energy.

There is a massive amount of material involved during these forty-one years of Jung's most productive work, in which Symbols of Transformation alone is nearly five hundred pages. It contains mythological references from the world over, many drawn from Friedrich Creuzer's multi-volume Symbolik und Mythologie der Alten Völker, which Jung had discovered as a youth in his father's library. To make this material more wieldy, I have chosen to explore the crucial stages of what I regard as Jung's most advanced descriptions of the archetypal process of psychic transformation and individuation in a self-contained literary context. For this purpose I have selected a coherent modern achievement of mythic and artistic genius, Thomas Mann's Magic Mountain. Mann was steeped in the same literary and philosophical tradition as Jung, especially that of Goethe, Schiller, Schopenhauer, and Nietzsche. The title of Magic Mountain comes from Nietzsche's Birth of Tragedy (23), and Nietzsche is on record for twice checking out Creuzer's work on mythology while writing Birth of Tragedy. Deepening the connection, Mann even lived for a while in Zurich. Biographers are unclear whether they actually met, but even if Mann is being truthful when he downplays Jung's influence on him, we should not be surprised in light of so many common sources at the many concordances that connect them. Furthermore, during the twelve years of composing the novel, Mann drew upon the stages of his own transformation brought about by the intervening disillusionments of WWI and political disagreements with his brother, Heinrich. Beginning as a German nationalist, Mann developed into an avid supporter of the Weimar Republic.

I would like to begin my exploration by discussing various possible meanings of Jung's comment in the foreword to the fourth edition of Symbols of Transformation that the book has a landmark status. After thus characterizing this book, I will then seek to demonstrate the revelatory powers, as applied to Thomas Mann's novel, of Jung's interpretation of transformative myth. Mann's novel exposes the unresolved issues of life and death in European society, which is about to plunge into the devastating chaos of WWI, the same period of Jung's most creative work. But just as Jung used myth as a seminal basis from which to criticize Freud, we can use Mann's mythic novel to criticize an aspect of Jung's residual scientific and personalistic inheritance from which he had not yet completely twisted free. That is, Jung's initial assumption, inherited from the Enlightenment, specifically from Descartes and the Cartesian interpretation of Kant, that consciousness is inherently encapsulated, underlies much of his terminology, and threatens to conceal his later, more phenomenological understanding of the psyche as openness and a priori connection. Although Jung does not go as far in the direction of openness as Mann, his insights nonetheless illuminate for us what we regard as the underlying structural dynamic of the novel, thereby emboldening us to take sides in the major bifurcation in the scholarship concerning Magic Mountain. That is, we argue against critics such as Rudolf Vaget and Alexander 


\section{Brown}

Nehamas who, sharing the narrator's often ironic attitude toward the "ordinariness" of Hans Castorp, claim that he is unable fully to assimilate his extraordinary experiences and that he backslides into his former bourgeois self in "The Great Stupor" and "Fullness of Harmony" sections of chapter seven. Against the defeatist notion of the novel, we support critics like Hermann J Weigand and Susan von Rohr Scaff who view Castorp's alchemical transformation as a continuing process of elevation into his highest possibility.

\section{I}

In the forward to the fourth edition, Jung describes Symbols of Transformation as "a place where two ways divided" ( $C W 5$, xxiv). The division of ways refers first, of course, to the inevitable break with Freud, who regarded the published redefinition of the libido as generalized non-sexual psychic energy as a personal and Oedipal affront and refused all further contact with Jung" (CW 5, xxvi). But the second and deeper level of meaning relates to the differences between Jung and Freud in their interpretations of myth, a topic that had originally attracted Jung to Freud. Jung describes how Freud's linking, in The Interpretation of Dreams, of a patient's incest fantasies with the Oedipus legend struck him as revelatory $(\mathrm{CW} 5$, par. 1). Jung had already assimilated Nietzsche's claim that the "atavistic element in human nature will manifest itself in dreams" ( $C W 5$, par. 27), which means, as people dream today, so ancient peoples once thought. This suggested to Jung a reciprocal relation between myth and dreamer; that is, mythic parallels could amplify our understanding of a patient's imagery, and that imagery could provide clues to the understanding of myth. Freud, however, read the connection only one way, regressively, by regarding myth, symbol, and even literature merely as pathological distortions of childhood sexuality. "The beginnings of religion, morals, society, and art," Freud wrote, "convene in the [sexual roots] of the Oedipus complex ... . , [which] constitutes the nucleus of all neuroses" (Freud 927). Accordingly, sexuality itself, with its irresolvable conflicts, should be the focus of study, not the myths.

Why is there such a diametrical opposition between Freud and Jung? The answer leads us to a more fundamental division of ways and directly to the heart of Symbols of Transformation. In "Two Kinds of Thinking," immediately following the introduction, Jung describes the first as Freud's kind of thinking, which Jung calls "directed thinking," a strictly modern achievement whose consummate form is natural science. Francis Bacon claims that of Aristotle's four causes, only the efficient and material causes are relevant to science, not the formal or final, teleological, cause (1451-66). Scientific explanation thereby requires a reduction of phenomena to their root material and motivating cause, which, for Freud's concept of neurosis, is always childhood sexuality. Jung describes this approach as constrictive and "unendurably narrow" ( $\mathrm{CW}$ 5, xxiii). He complains of Freud's "reductive causalism," which almost completely disregards the "teleological . . . so characteristic of everything psychic." In opposition to directed thinking, that is, to the entire tradition of scientific thinking of the Enlightenment, Jung proposes a 
retrieval of the pre-scientific associative method described by William James, which Jung later elaborates as "thinking in primordial images, in symbols which are older than historical man . . . inborn in him from earliest times, . . . [the] eternally living ... ground of the human psyche" ( $C W 8$, par. 794). Thus, the truly landmark significance of the book's division of ways is not really Jung's break with Freud but rather the historical shift in psychology from logos to mythos, a method of thinking that the rest of Symbols of Transformation will demonstrate.

\section{II}

What suggests the protagonist of Magic Mountain as a candidate for Jungian analysis? Joseph Campbell calls the novel "a landmark in the field of mythological research, . . . representing the passage of a modern man, stage by stage, through initiations in effect equivalent to those of the ancient mysteries" (Creative Mythology, 325). If we accept Campbell's high regard for Mann's novel as mythic source material, then we would expect not only to find many of the same stages of transformation that Jung has painstakingly traced in Symbols of Transformation in relation to the fantasies of the American journalist, Miss Frank Miller, but we should also be able to determine how Hans Castorp avoided the disintegration Jung feared for Miss Miller. ${ }^{1}$ The highly crafted level of Mann's literary work affects our approach. In explicating the Miller fantasies, Jung drew upon his vast knowledge of mythology to fill gaps in Miss Miller's notes. In Magic Mountain, Mann himself supplies adequate hints in the novel's subtext to alert the reader to the appropriate mythical amplification, which makes our study more manageable and less arbitrary.

The story is structured by a young man's initial three-week visit with his cousin at an exclusive tuberculosis sanatorium in the Swiss Alps, where he unexpectedly remains for seven years, receiving what we might call a truly higher education. Joseph Campbell, in discussing the novel, summarizes what Jung calls the psychic transformation symbolized by a mythic hero. Campbell describes the process according to the three stages of rites of passage: separation, initiation, and return. That is, as Campbell writes, "A hero ventures forth from the world of common day into a region of supernatural wonder: fabulous forces are there encountered and a decisive victory is won: the hero comes back from this mysterious adventure with the power to bestow boons on his fellow man" (Creative Mythology 362). Mann's novel, of course, is a tragedy. The fact that he takes the title from Nietzsche's Birth of Tragedy should alerts us to the exemplary nature of Hans Castorp's accomplishments, despite their obliteration through his likely death on the battlefield at the end. The novel stands as a testament to the prescience of Jung's advance beyond Freud's regressive reading of myth. Of greatest significance for Jung's interpretation of myth is that regression, which may occur during an interruption in one's engagement with life, whether through depression, neurosis, accident, or simply need for a new adaptation ( $C W 5$, par. 450), should be deflected from the instinctual, physical sphere. That is to say, rather than surrender to infantile passivity or escape into sexual evasion, which is the Freudian understanding of longing for the mother, the regressive impulse should be diverted instead by means of a symbolic matrix toward a progressive process of 


\section{Brown}

individuation. Regression in the service of development, symbolic replacement of the mother and father with a mythic matrix, is, according to Jung, an evolved potentiality of human nature. The longing for the mother, or for the anima archetype, is only apparently a longing for the real mother. What is actually longed for, according to Jung, is the gateway into the realm of the Mothers, the prenatal realm of the Eternal Feminine where, among all the archetypal possibilities, slumbers the "divine child," the germ of wholeness ( $C W 5$, par. 508). But, as Jung points out in the Epilogue to the Miller fantasies, the archetypal meanings must be assimilated into one's life and conscious attitude in order to be effective.

\section{III}

In Magic Mountain, we meet our protagonist, Hans Castorp, on the train high in the Swiss Alps. Having just graduated in engineering, he is scheduled to begin an unsalaried position in his uncle's shipping firm. From his alligator valise, his silk-lined overcoat, and his belief that a meal is unfinished if it does not end with sherry and a cigar, we learn that he is the pampered scion of a prominent family. We are also told that he does not glance at a book relating to his career that he brings along, Ocean Steamships (MM 6). Upon arrival at the sanatorium, Castorp finds the thin mountain air, the remoteness from ordinary life, the unseasonable extremes of weather, his cousin's disregard of ordinary temporal urgencies, and the open talk of sickness and death all very disquieting. Everything about the Berghof seems strange and enchanting. It is mid August but freezing cold. Not only are the seasons up here out of whack but he learns that time has a different meaning than in the flatland below. In short, his cousin tells him, this is where a man changes his ideas (MM 7).

In chapter two, we learn that Castorp's mother and father died when he was six and seven, respectively, and that his beloved grandfather, an ex-senator, whose mannerisms he adopted, died eighteen months later. Accustomed by then to funerals, little Castorp felt sadly uplifted by the wonderful music and sacred space of ritual, and he loved to ponder the continuity of life through the generations, seven of which had already signed the family's baptismal bowl. His uncle took over as a foster parent, executor, and, after college, offered Castorp, not the secure job of the real sons but at least an unsalaried starting position.

We see then at the beginning of our story that the young engineer has chosen a technical profession that does not coincide with his early emotional response to funerals and that his stiff persona is modeled on his aged grandfather's sense of decorum. In short, he is an unconsciously fragmented puer of the German bourgeois class, suffering as yet unknowingly from a disjunction of his inner and outer being, a dissociated condition of cultural modernity already diagnosed by both Schiller and Nietzsche and experienced by Freud and Jung through their patients. The transformation of this fragmented caricature into a human being is the task of the novel.

Thomas Mann originally published Magic Mountain in two volumes, the first tracing in the hermetic environment of the sanatorium the descending path of 
Castorp's ego dissolution and simultaneous shattering expansion of his awareness. This volume, containing five of the novel's seven chapters, ends during the Walpurgisnacht episode with Castorp's symbolic death and rebirth in an alchemical coniunctio (union of opposites). Its structure is sufficient to demonstrate Jung's argument in Symbols of Transformation that the goal of regression in service of higher development is a rebirth of one's being. But the second volume will trace Castorp's ascending path well beyond the ordinary accomplished life into the rarified further reaches of true individuation.

The first day of Castorp's visit fills a chapter appropriately called "The Shadow of Respectability." Here Castorp endures repeated assaults to his sense of propriety, which accords with Jung's notion that the first stage of one's expanding awareness requires recognition and owning of one's shadow, one's negative assessments. Jung describes such an experience as archetypal because changes in one's psychic habits and stability cannot be accomplished through intellectual choice alone. Only the archetypes are powerful enough to divert habit and instinct into a new direction. The shadow begins to emerge when Castorp's Russian neighbors upset him with their daylight sexual romps; then his tablemates at lunch offend him with mangling the German language, and finally someone he does not see rudely slams a door. But, as a guest, he must accept these indecorous realities and perhaps even come to understand them. At lunch, after the next rude slamming of the door, he learns the identity of the negligent culprit, a certain Madame Clavdia Chauchat (French for clawed hot cat), whose high cheek bones and slanted eyes somehow become fascinatingly unforgettable to him, despite her belonging to the general unsavoriness of the milieu (MM 75). The fascination animates his unconscious, already awakened by the disquieting judgments that revealed his shadow self. Precisely as Jung informs us, the archetypal experience most likely to follow the stirring of negative reactions that announce the shadow, at least for a man, is the anima, the female archetype. Behind each kaleidoscopic shift in the possible array of embodied archetypes, beginning with the shadow and anima, stands the remainder of the unknown psyche, assimilated in such stages. We know that even for Jung, habituated as he is to the metaphor of inwardness and depth, these structures are first discovered in the field of experience as surplus meanings invested in people, situations, and events and only later recognized as our own unexpected mirroring.

After his discovery of Madame Chauchat, Castorp is approached by a figure who at first seems merely comical but who becomes a major intellectual force in Castorp's life at the Berghof, Ludovico Settembrini. Settembrini shocks Castorp by asking him why he descended so low as the Berghof. He then deflects Castorp's protest that he climbed five thousand feet to get here as an illusion, claiming that he has really, like Odysseus, begun a Nekyia, a visit to the underworld. We learn from this the interchangeability of the metaphors of depth and height, a lesson we will apply to "depth" psychology. Settembrini refers to the head of the Berghof, Dr. Behrens, not only as Rhadamanthus, whom we know as judge of the dead, but also as a man who catches birds ( $M N 59)$, which is a reference to the alchemical theme in Mozart's Magic Flute, where Tamino, like Castorp, falls in love with a woman he has only seen but not met. Since we know that in the opera, Tamino's union 


\section{Brown}

with Pamina will be a rebirth, a symbolic hieros gamos (sacred marriage), we touch upon some of Mann's multiple mythic amplifications of Castorp's story (MF 19ff.).

Psychologically, Castorp, separated from his familiar world in flatland, is both attracted and repelled by events at the sanatorium; as his worldview is deconstructed he even loses his sense of up and down. In the alien air, he feels hot, cold, and cannot stop thinking of a woman he holds in contempt. While Settembrini tells him to leave while he still can, Madame Chauchat walks by, and Castorp protests that he could not possibly leave now. We see Castorp hooked by both the anima and the animus-here, guide or intellectual mentor-as his unconscious psyche runs ahead of him, with the insufficiencies of his past drawing him into the future.

Chapter four details the remaining weeks of Castorp's planned visit. Still fascinated by death and sickness, Castorp loves to look at coffins. Settembrini excoriates this Romantic predilection of Castorp's regarding the nobility of sickness. But, here again, an instinctive inclination, however derived, cannot be diverted, as Jung points out, through the intellect alone. Only the transformative power of the archetype can oppose the power of another archetype, in this case, Thanatos. Castorp has a dream in which Madame Chauchat plays the part of a youth whom Castorp as a boy distantly admired and who possessed the same oriental-Russian eyes (MM 88ff.). He suddenly recognizes the source of his fascination as being rooted in this past experience. But does he fully? This boy's name was Hippe, an old word for scythe, such as carried by the figure of death. To Settembrini, the narrow eyes of Madam Chauchat, evocative of Russian vastness, mean formlessness, and he tells Castorp that for a German this portends death. Castorp's attraction for this woman, as we see through his rekindled memory from boyhood, is regressive; but since he was even then already fascinated, it must also suggest something archetypal, some longing for dissolution, similar to a Wagnerian blend of love and death. While volunteering to help dying patients, Castorp arranges to pass Madame Chauchat as often as possible in the hallways, thereby compulsively stalking this woman whom he still considers socially beneath him. She once reads his death-inspired sadness as the look of love and blushingly touches her hair. Increasingly obsessed with her, caught in the mesh of this complex attraction, Castorp even starts coming late to meals and slams the door behind him. Throughout the novel Castorp absorbs qualities from each archetypal character, thereby expanding into discovered parts of himself while further losing his initial ego identity. To enter her world, he has assimilated his shadow. Stressed over his impending departure as his allotted three-week visit draws to its end, Castorp listens to music on his cold balcony, runs a fever, visits Dr. Behrens, and happily becomes a patient, no longer free to leave (MM 178).

In chapter five, detailing the seven months leading to Walpurgisnacht, the story takes an unexpected turn. Castorp, his identity further dissolved, confined as a new patient to bed for three weeks, is exposed to meaningless time. His emotions, deprived of any ordering principle, careen from triumphant joy to pale trembling fear. Thinking over his life, he sees that he cannot continue as he is but needs a more authentic perspective. Settembrini has warned him that within six months 
every young person who comes up here to the Berghof has nothing in his head but flirting and taking his temperature. This gives us a standard to judge Castorp's difference.

Though consumed by thoughts of Madame Chauchat, Castorp also heeds Settimbrini's warning that he was not Odysseus enough to approach this Circe unharmed, who would soon have him walking on all fours and grunting like a pig (MM 243). Caught in a war of opposing archetypes, needing a new orientation, Castorp channels his instinctive desire into a craving for knowledge under the auspices of Eros. While Madame Chauchat's image hovers in the shadows of his room, Castorp studies mineralogy, chemistry, basic biology, embryology, anatomy, and the interrelation of the various human disciplines (MM 266ff). He studies parasites, bacilli, and infectious tumors and observes how disease manifests life's most lascivious form. But none of these answers the fundamental question: What is life? Falling asleep at his desk, he feels the image of Clavdia Chauchat hovering over him with sweet embrace $(M M, 281)$. We can regard his vast absorption of knowledge as a defense against the loss of control over his life and the confusion he feels, but also as the potential building blocks of a new way of being, a way of forging a new identity. He afterwards claims, "I used to be an engineer" (MM 288). His quest for knowledge also serves to shift his regressive instinctual desire to the archetypal plane, which, as Jung argues in Symbols of Transformation, is a crucial step in a symbolic rebirth.

On Walpurgisnacht (MM 316ff.), at the end of seven months at the Sanatorium, Clavdia Chauchat comes to the ballroom dressed in black, like death. Settembrini warns Castorp away from this Lilith, but Castorp has come far enough to push him aside and, pale with fright, approach her anyway. He insists on using the familiar form of address with her, despite her initial protest. To speak familiarly with her is why he waited so long to approach her, he tells her, but we know that he also had first, through study, to raise his stature. He had to be able to approach her at the right level. Castorp tells her that they are in a dream, an eternal dream, one that he has dreamed for a long time. "Behold!" he tells her, Nietzsche like, "“Eternity" (MM 331). Jung writes in Symbols of Transformation that there is "nothing intrinsically absurd about the expectation that [an archetype] will take over the activity and spontaneity of the conscious mind, for the primordial images are quite capable of doing precisely this" ( $C W 5$, par. 260). She tells Castorp that she is leaving the sanatorium the next day. He is stunned, saying that he has waited seven months for this moment. Because of her connection with Dr. Behrens, she has inside information. She tells him that his cousin is dying. Castorp says, "his condition is very like my own . . . he is dying, and me, I am in love-fine!" (MM 334). For Castorp, she is no longer merely a woman, but also a goddess, one who has always been with him. She is death for him because he is in regression. But she is also life because his connection with her is transformative. In contrast to his old personality, his bold approach to her is a symbolic dying into his opposite, a merger of love and death that simultaneously consummates for him a new beginning. Demonstrating how far he has come, Clavdia, who previously refers to him as bourgeois, now finds him harder to characterize. "You are indeed a gallant suitor" (MM 337) she tells him, "one who knows how to woo in a very profound, German fashion." Recognizing that he has achieved a kind of symbolic wholeness, she 


\section{Brown}

broadens her description to "A bourgeois, a humanist, and a poet-behold, Germany all rolled into one, just as it should be." The original Volume I of the novel ends as she leaves Castorp standing in the ballroom, but her last words to him are, "Don't forget to return my pencil" (MM 338).

This situation could easily have formed the finale of a lesser novel, especially with Clavdia inviting Hans into her bedroom. But by rejecting such a conventional ending and, instead, delving deeper into the means of integrating a fragmented personality, a task preceded and inspired by alchemical, literary, philosophical, and psychological writers such as Paracelsus, Goethe, Schiller, Nietzsche, and Jung, ${ }^{2}$ Mann has transcended the bourgeois limitations of the traditional Bildungsroman in order to reach a new and heightened understanding of the human being. Heidegger, from purely philosophical resources, has pushed in much the same overall direction of an authentic self-fulfilling individuation in his three increasingly detailed studies of Plato's myth of the cave." 3 Heidegger's temporal ontology and the transcendental openness of Dasein's primordial understanding provide a hospitable conceptual and terminological framework for the processes that Jung has discovered and elaborated (Being and Time 120).

Clearly, without the transpersonal experiences and reciprocal interactions of the Berghof Umwelt, without the presence of Madame Chauchat, Settembrini, and others, Castorp could never have undergone his transformation. The necessity for intersubjective involvement leads us to criticize Jung's early theoretical notion of the encapsulation of consciousness that still clings to some of his terminology, a notion inherited from Freud, Kant, and, ultimately, Descartes. Jung writes such things as "there is, in a certain sense, nothing that is directly experienced except the mind itself" ( $C W$ 8, par. 623) and "he is shut up inside his mind and cannot step beyond it" (CW 11, par. 765). Roger Brooke comments that in these and similar passages "Jung is guilty of enclosing psychological life into a solipsistic inner world from which, among other things, it is impossible to speak coherently of any real relationship with other beings" (109). Yet in practice Jung transcends this limit, as when, for example, he speaks of participation mystique or of transference. Describing transference, Jung writes "The unrelated human being lacks wholeness, for he can achieve wholeness only through the soul, and the soul cannot exist without its other side, which is always found in a "You." Wholeness is a combination of I and You, and they show themselves to be parts of a transcendent unity whose nature can only be grasped symbolically ..." (CW 16, par. 454). Such insights completely shatter the default notion of an encapsulated consciousness with which Jung begins and sometimes falls back on when he speaks theoretically, which is not his strong point. Further supporting Jung's evolving notion of the psyche from enclosure to openness, the Jungian analyst John Ryan Haule quotes a description of Jung's gestural explanation in 1934 of a shared psychic field to an analysand: "With brief, firm gestures [Jung] touched first my forehead, then his own, and thirdly drew a giant circle with his hand in the space between us. ... In short, one doesn't dream here, and one doesn't dream here, one dreams there." " (290). Accordingly, in my analysis of Mann's Magic Mountain, I point out that the experience of archetypal psychic contents does not occur deep within the 
encapsulated individual psyche, but always happens in the indwelling distance between an individual and what appropriates him. Furthermore, Jung's convergence here with Heidegger's phenomenological ontology of Dasein lets us suggest that even for Jung, especially the late works, "The world is opened up to Dasein, which at the same time opens Dasein up to itself" (Heidegger, The Concept of Time 56). The basis for a reframing of Jung's terminology would be to interpret the psyche, or soul, as Dasein; that is, as openness to the site of experience, a site into which we are thrown and already determined by linguistic and cultural historicity. We will revisit Jung's notion of wholeness as a transcendent unity at the end of Volume II of Mann's novel, where we will argue for the possibility of going beyond a merely symbolized unity by actually surrendering to an experience of a fully aware and undifferentiated joyful wholeness.

\section{On Volume II}

By ending the original Volume I of Magic Mountain (chapter five) with the purely symbolic completion of Hans Castorp's death and rebirth, which take place through his declaration of love for the terrifying and alluring Clavdia Chauchat, Mann revealed the fulfilling significance of the archetypal, but not physical, hieros gamos. But with this bold step, which introduces a disjunction between the plot and the action, Thomas Mann demonstrates his intention to go beyond the limits of the traditional, bourgeois Bildungsroman and also beyond Jung's trust in symbolic resolution. We have already seen that Volume I ends with Castorp standing alone in the ballroom while Clavdia Chauchat leaves for her room, albeit with the enigmatic remark that he should not forget to return her pencil. The hint suggests a possible delayed resolution.

\section{I}

Despite this slight letdown of romantic expectations by stopping short of consummation, Volume I seems dramatically complete on the symbolic level. Castorp is no longer the same entitled, blasé, and fragmented bourgeois German that he was upon his arrival at the Berghof. He has confronted his shadow, accepted his inferior aspects, acknowledged his unconscious motivations, and modified his fascination for death by tending to the dying. Even Clavdia Chauchat recognizes his significant development with her surprised expostulation that he is now " $A$ bourgeois, a humanist, and a poet-behold, Germany all rolled into one, just as it should be."' By approaching this woman whose otherness reflected death, Castorp breaks through the flow of time to experience an archetypal nunc stans, which he expresses with his self-assured claims of their already eternal togetherness. Jung describes a similar event in Symbols of Transformation when he writes that "in modern psychological language, this projection of the hieros gamos signifies the conjunction of conscious and unconscious, the transcendent function characteristic of the individuation process. Integration of the unconscious invariably has a healing effect" ( $C W 5$, par. 672). In that moment (Augenblick), Castorp reaches symbolic wholeness.

We might regard Mann as pushing transformation further than Jung's Symbols of Transformation in that he does not rest satisfied with a merely symbolic healing. 


\section{Brown}

It is only in Jung's alchemical work that we can say that he nearly approaches the alchemical insights of Magic Mountain's existential liberation. Volume II, chapter six, begins with general reflections on time and the many changes at the Berghof. We rejoin the story in April, six weeks beyond Walpurgisnacht. But we are flashed back to that night. Castorp did return Clavdia Chauchat's pencil, the only time it could have been returned. Her comment allowed them to leave the ballroom separately to reduce gossip. By postponing such a significant event-the sexual consummation that solidifies Castorp's new identity - into the second volume, Mann initiates a fresh series of events instead of simply culminating those that have already occurred. Although Madam Chauchat, as promised, left the Berghof the next afternoon, her memory served Castorp afterward as the genius and guardian angel of the sanatorium. He had, of course, during that "wicked, riotously sweet hour" (MM 344) in which he possessed her, made mad suggestions of traveling Europe and Russia together. One imagines that Mann had the Russian travels of the poet Rene Rilke with Madam Lou Salome in mind as he described this Russian enchantress. But Madam Chauchat had to know that in Castorp's fantasy she was more archetype than woman. He, accordingly, lacked the power to hold her. $\mathrm{He}$ did, however, obtain a vague promise that someday she would return, and she let him have the X-ray picture of her headless upper body as a keepsake, with its ghostly hints of lungs and the flesh that encompassed her bones. He kept this keepsake in his breast pocket and took it out often to press his lips fervently against it (MM 343). Acknowledging Jung's discovery that a chaotic, restructuring soul needs a symbolic center around which to collect a new identity, we can see the positive function of her x-ray photo as a beloved fetish. We should not ignore here, in light of the incomplete psyche's drive toward wholeness, Kant's contribution to the issue of recentering with his notion, in the Critique of Pure Reason, of the regulative unifying principle of reason (A619/B647).

At this point, we need to ask where we are in the novel. Even the narrator wonders which part of Castorp's "mixed character would prove the stronger, the bourgeois or the other?" (MM 344). Leaving "the other" undefined, hints at an issue that still divides critics: how the novel ends. The changes at the Berghof itself refer to the many departures by people wanting to get on with their normal lives in flatland. In addition to the departure of Madam Chauchat, Castorp's cousin, Joachim, the sole reason Castorp came to the Berghof, has grown impatient with the aimless ups and downs of the Gaffky scale that measures his bacterial count (MM 340). With this uncertainty whether he is getting worse or better, Joachim resolves, even if it kills him, to leave the Berghof at the end of the month. Even Settembrini-who has not spoken to Castorp for the six weeks after Castorp's rude behavior on Walpurgisnacht (he spoke familiarly to Settembrini and pushed him aside to approach his Lilith) — comes by to announce his departure. Seeing that he is not getting better, Settembrini settles on more affordable living arrangements in the village. In a fit of pique at these refusals of his advice and the consequent loss of revenue, Dr. Behrens tells Castorp that he, too, may as well leave, a suggestion that Castorp does not take seriously. These departures serve to emphasize Castorp's decision to remain on at the Berghof in order to pursue what we must interpret as 
his spiritual cure. At his stage of hard-won maturity, we suspect that Castorp could do well for himself back in Hamburg, where his grandfather had been a senator. Yet he stays at the Berghof, not accidently, but resolutely.

We need to make clear that individuation, although an inborn possibility of human development and an archetypal process with its own teleological structure, is not automatic or common and does not necessarily enhance the path of worldly attainment. It is for those rare human beings who are willing to leave the well-worn paths of human expectation and make the sacrifices required, with no guarantee of success, to achieve the experience of wholeness. Already in the Republic, Plato saw the often either/or choice between tending to worldly success or tending to the soul (periagoge). This is why Jung describes individuation "as a relatively rare occurrence that is experienced only by those who have gone through the wearisome but, if the unconscious is to be integrated, indispensible business of coming to terms with the unconscious components of the personality" ("The Spirit of Psychology" 433). Jung describes their kingdom as "not of this world" ("The Spirit of Psychology" 419). In Volume II Mann makes his original push deeper into what was a previously little-known and inadequately explored territory of the human psyche. Volume I by itself would have been an important novel, but Volume II represents an advance in the Western understanding of the human being. By remaining at the Berghof, Castorp resolves to embrace a process that he intuitively feels is moving toward an unknown but deeply authentic goal, a goal presently, but vaguely, associated with the eventual return of Clavdia Chauchat, the current symbol for him of his completeness.

\section{II}

To obtain a rough outline from our Jungian perspective of the tasks remaining in Castorp's extended adventure, it will help us to revisit the period in Jung's career leading up to the writing of Wandlungen und Symbole der Libido, when he parted ways with Freud and discovered a new psychic structure. Jung and Freud, in what was both the highpoint and finale of their relationship, traveled together for seven weeks in 1909 on a lecture tour to the United States. During this period they exchanged and attempted to interpret each other's dreams. According to Jung, much to his disappointment, Freud withheld contextual information concerning his own dreams "in order to preserve his authority" (Memories 158) and, furthermore, could not satisfactorily interpret Jung's dreams, which contained what Jung later calls collective material. One of these dreams in particular, to which Jung later attributes his discovery of what he calls the collective unconscious, will serve us well in our quest to understand the second volume of Mann's novel.

In this dream, Jung finds himself in an unknown house that belongs to him. $\mathrm{He}$ is on the upper floor, richly furnished in rococo style with fine old paintings but is intrigued by what might be on the lower floor. He descends the stairs and finds everything there much older, hailing from the fifteenth or sixteenth century. Opening a heavy door, he follows a stone stairway down to a cellar, where he recognizes stone blocks and chips of brick as Roman era construction. In the floor he finds a ringed stone slab that, when lifted, reveals yet further depths leading into 


\section{Brown}

a cave cut into the rock. In the dust of the floor are scattered bones, pottery shards, and two half-disintegrated human skulls (Memories 158-59).

In discussing this dream with Freud, Jung reports in Memories, Dreams, Reflections that he realized the severity of the breach between them. Of all the images, Freud was interested only in the identity of the skulls, which to Jung meant that Freud wanted to hear of Jung's death wish toward him. Jung writes that he lied. Does this mean Freud had been right? Jung claimed that they were the skulls of his wife and sister-in-law, and interpreted Freud's reaction as relief. At the very least, even if Freud did not detect Jung's lie, the trust between them from both sides was obviously broken. Regarding trust, Jung makes no mention in his one-sided description of their break of his own scandalous involvement with Sabina Spielrein, about which Freud knew and disapproved (Bettelheim 57-81). Jung claims that in the days preceding the dream he had been wondering upon what premise Freud's psychology was founded and what was the relation of its nearly exclusive personalism to the general historical situation (161). Regarding the dream as an answer to these questions, Jung relates the successive layers of cultural history to the successive layers of consciousness, noting that they represent an impersonal component in the human psyche. He takes the dream as "a kind of structural diagram of the human psyche" (161).

The dream makes clear to Jung that self-realization involves more than resolving the residual conflicts of one's early domestic situation but that we are, as Heidegger might put it, thrown into the historicity of our cultural and human situation. At this point, Jung still embraced an encapsulated notion of the psyche, which the dream imagery simply elaborated into more levels of interior depth. But the notion of levels, and hence the core insight of the dream, holds true even for Jung's later embrace of a more Heideggerian openness of the psyche. In fact, openness to the historicity of the world is the only way to understand these levels. In Memories, Dreams, Reflections, Jung mischaracterizes the levels as a priori, which means, as Jung surely knows, prior to all experience. But knowledge of the fifteenth and sixteenth centuries and of Roman methods and materials of construction is hardly a priori. Instead, such historical knowledge is completely $a$ posteriori and requires psychic openness to one's context in an already meaningful historical situation. What is genuinely a priori, however, is the structure of the human psyche such that historical knowledge sinks into appropriate levels of relative unconsciousness. But such levels, and the forces still active in them, must be sublated from mere knowledge into the temporal situation of one's self-identity. Without this historical and transpersonal awareness, one remains simply an anonymous, isolated, and incomplete individual aggregated into the herd. True individuation requires fully occupying one's historical and cultural identity. Jung's break with Freud, he informs us in Symbols of Transformation, was a break with personalistic psychology (a break we consider incomplete). Even though Jung's major thematic focus was the ever-present influence of the mythical archetypes of the collective unconsciousness that guide human behavior, the historical situation was, nonetheless, also important to him. This we can determine not only by the importance he attributed to alchemy as providing historical continuity with the 
ancient world but also from his horrific dreams just prior to WWI, which, of course, coordinates with similar contemporary events depicted in Mann's Magic Mountain.

III

Returning to Magic Mountain, we see that Castorp realizes intuitively his need for the hermetic isolation of the Berghof to follow his obscure impulse toward its unknown goal. The process of individuation remains highly paradoxical because it must be chosen yet cannot be directed. It involves surrender within resolve, which Jung describes in Symbols of Transformation in the chapter called "Sacrifice": "It is a natural, unconscious process, a collision between instinctive tendencies, which the conscious ego experiences in most cases passively because it is not normally aware of these libido movements and does not consciously participate in them" ( $C W 5$, par. 660). Castorp, opposing his cousin's eagerness to regain the freedom of flatland to carry on with his military career, exclaims, "'Freedom dwells within the mountains!" ( $M M$ 379). He even ignores Settimbrini's warning that the situation at the Berghof might be precarious, like a luxury liner on the deep (MM 350). The vague sense of higher possibilities of life yet to be realized prevents Castorp from leaving the Berghof. He does, however, begin to venture out a bit.

New possibilities arrive with the advent of spring, when Castorp begins to gather wildflowers from the nearby mountain paths and study them, as well as to scrutinize the starry skies. Joachim, biding time before his impending departure, complains of Castorp's constant learning, of his growing past him, and accuses him of sounding more and more like Settembrini. In proclaiming that they were there to get well, not to learn, Joachim asserts the status of collective norms against Castorp's increasing individuation. Such a dialogue differentiating Castorp from the norm should serve as a caution to critics like Vaget and Nehamas who regard Castorp as too ordinary to transform himself. Joachim, despite his protest, accompanies Castorp into the village, where they discover a new major character, Leo Naptha ( $M M$ 366). Naptha is an intellectual companion of Settembrini's who had previously inhabited the Berghof but who, like Settembrini, upon learning he was incurable, decided to finish his days in the village while teaching at a local school. Settembrini has taken up residence, like a poor church mouse, in the garret of Naptha's building. An apostate Jew trained as a Jesuit who afterward converted to Communism, Naptha is riddled with dangerous self-contradictions and represents the diversity of threats to European culture.

Castorp divides his time away from the Berghof between exploring of the wooded mountains and participating as a listener in the interminable and increasingly polarized intellectual arguments between Settembrini and Naptha. Settembrini advises Castorp, who spends hours with them, to avoid taking sides or endorsing either viewpoint. This advice is consistent with Jung's position in Symbols of Transformation that "the self, as a symbol of wholeness, is a coincidentia oppositorum, and therefore contains light and darkness simultaneously" ( $C W 5$, par. 576). But until a balance is found, the individuation process, Jung tells us, is plunged into a "chaotic multiplicity ...., dualism[s], 


\section{Brown}

opposition of light and dark, of upper and lower, right and left," and Jung, too, counsels that the ego can maintain its integrity "only if it does not identify with one of the opposites" ("The Spirit of Psychology" 413-14, 429). These intellectual arguments with the complex Naptha bring out the contradictions in Settembrini, who is an Enlightenment rationalist, a Mason, and a Greco-Roman Classicist. Their arguments cover an enormous range of historical issues drawn from the ancient dual origins of the Western world in Athens and Jerusalem and connect these, along with issues of the Middle Ages, with the conflicts festering in the first decade of the twentieth century. Castorp follows the increasingly hostile arguments with a keen interest, since they both enact his inner chaos and connect him to his historical roots. We could say he is becoming acquainted with the lower floors of Jung's unknown mansion and thereby coming into contact with the historical forces that are an inextricable part of his forming identity. But whereas these oppositions at first seem to encompass all possibility, Castorp gradually becomes aware that Settembrini and Naptha are actually alike in their one-sided intellectuality. Their pale skin reveals detachment from the vitality of nature. Their absorption in logos touches off an enantiodromia (reversal of course) in Castorp toward nature in the Greek sense of physus.

As winter arrives, Castorp violates the Berghof's rules by secretly purchasing ski equipment, which he stores with Settembrini, who approves of such bold initiatives, and begins taking forbidden treks in the snow in order to learn the sport. This effort combines Madam Chauchat's praise of risk, Naptha's praise of the courage to enact one's ideas, and Settembrini's encouragement to enjoy, rather than just gape at, the snow. Castorp assimilates something from each sequential influence, each archetype that manifests itself in the surplus of meaning he finds in the series of people who fascinate him. One afternoon, headed on skis deep into the woods, he is diverted by an unseen culvert just as a sudden blinding snowstorm overtakes him. After trying to find his way back, he runs into his own tracks and realizes that he has lost his way and is merely circling. Finally, exhausted and freezing, he takes shelter from the blinding fury behind the wall of a small structure. A sip of brandy makes things worse, and he begins to lose consciousness. He dreams he is on a warm balcony listening to the sweet singing of birds. A curtain of rain falls away, and he sees the Mediterranean Sea with its deep blue sparkling water. Half dressed lads and maidens cavort on shore. "How pretty and clever they are," thinks Hans (MM 482). Then as Hans climbs the steps of a temple, one boy turns into stone. As Hans goes behind the temple, he sees two half-naked old women dismembering with their bare hands a child above a basin (MM 485). Blood drips from their mouths, and they devour the tiny body piece by piece, with the bones cracking. Seeing him, they scream obscenities in the dialect of his home town. Shrinking back, he becomes aware of being in the snow with ski clothes on. "How could I know such things?" he asks himself in astonishment. "We must be able, he realized, to dream beyond ourselves anonymously and communally" ( $M M$ 485). It occurs to him that we are little pieces of a great soul that dreams an eternal dream about youth, hope, joy, and the bloody feast at the end. Becoming more awake, thinking of how much he has learned since arriving at the Berghof, he 
realizes that he has experientially passed beyond Naptha and Settembrini, whom he now regards as windbags ( $M M$ 486) and that his allegiance now is with this little community of human beings cavorting while the bloody feast is taking place. This establishes in him an archetypal reorientation. Hans realizes that life and death are not contradictions or opposites, but are inextricably linked. He vows, in the interests of love, to keep faith with death in his heart but not to grant it dominion over his thoughts (MM 487). This is the fundamental insight he had long searched for. His heart beats strongly, his spirit is happy, and the dream has refreshed him. Vowing to live, he wrenches himself free from the snow and sees the weather is clearing. Castorp has experienced something of the primordiality that in Jung's dream is represented by the two skulls lying among the shards in the rocky cave. Castorp sees his origin and center now in a mythical matrix rooted in his Nietzschetinged understanding of antiquity.

The symbolic unity that Hans Castorp achieves by the end of Volume I, a unity still embedded in ordinary reality, has now become, through a leap, existentially manifest on a much higher level. Jung describes such a transformation as becoming free from the instinctual level to apprehend oneself within the archetypal level of spirit, a level outwardly expressed in the world's myths. Castorp's long-sought truth, discovered in his profound transpersonal experience, replaces the X-ray picture of Clavdia Chauchat as the new center of his being and seals his relation to life. But his decision to live rather than to die in the snow shifts his experience from the merely symbolical to an existential resolve, a level of being that exceeds the symbolic unity - which Jung describes as the telos of myth in Symbols of Transformation-achieved in the heiros gamos at the conclusion of chapter five. So, although Jung's insights enable us to understand the hidden dynamic of Magic Mountain, the novel nonetheless transcends the symbolic immanence of Jung's theory. At this point, Hans, ironically, though appropriately, gets word that Clavdia Chauchat is returning. We know, of course, from Heraclitus, whom Mann admires, that one can never step into the same river twice, even though Castorp, for his part, does not yet suspect this. The difference is clearer to her, since she arrives in a manner he does not anticipate. She is accompanied by a larger than life colonial Dutchman from Java, a coffee planter, tall, rich, sixty years old, with flaming white hair on his impressive head. They make their relationship clear by taking adjoining rooms (MM 538ff.). Although Castorp reacts with shock and complains to Dr. Behrens about the Dutchman, the doctor points out that although the new arrival is filthy rich and travels with a Malayan valet, he suffers from alcoholism and intermittent, but protracted and chronic, tropical fever. When Castorp first talks to the now-reserved Madam Chauchat, mocking her companion's habit of speaking in broken sentences, the large man, Mynheer Peeperkorn, suddenly appears so close to him that Castorp has difficulty standing up from his chair. Castorp feels crushed by the man's massive personality, broad shoulders, red face, and his flaming white hair like a lion's mane. Peeperkorn is magisterially courteous, however, saying: "My dear sir, permit me, I am making your acquaintance this evening. I like you. Settled. Don't mention it. You appeal to me" (MM 551). Castorp is silenced, and soon afterward falls as much under Peeperkorn's spell as he has previously been under Madam Chauchat's. We are immediately reminded of the Red Book, in which the anima, sometimes in the 


\section{Brown}

aspect of Salome, accompanies and leads the Grand Old Wise Man, sometimes in the form of Elijah (245).

Peeperkorn, with his powerful presence and inarticulate vitality, stands in archetypal opposition to the loquacious infirmities of Settembrini and Naptha. In Nietzschean terms, he seems an instance of formless Dionysian energy as opposed to the Apollonian exactitude of Castorp's pale mentors in the village. Because of Castorp's freshly achieved commitment to vitality resulting from his apotheosis in the snow, he is prepared to appreciate this man of the world. During one of Peeperkorn's bouts of fever, Castorp takes care of him as he has previously done for dying patients. He and Peeperkorn even come to an agreement over Madam Chauchat, with Castorp receiving advice on women and love. Since Peeperkorn was in no condition to give Castorp the satisfaction of a duel, he proposed instead a little rite of brotherhood ( $M M$ 556). In this way the fatherless Castorp received the virile recognition of a powerfully masculine man. He let the man's commanding presence silently work on him.

Castorp even takes Madam Chauchat and Mynheer Peeperkorn along to the village to visit Settembrini and Naptha. "'In God's name, my Good engineer," said Settembrinni after a while, "'what do you see in him, he is just a stupid old man"" (MM 573). But Naptha and Settembrini are reduced to silent shadows beside this powerful figure treating them to luxurious delicacies at a restaurant. Peeperkorn, on one outing, points out to them, rivaling Nietzsche's Zarathustra with his companion animals, an eagle flying high in the sky and described its magisterial capabilities (MM 582). On their last outing, Peeperkorn takes them all to a roaring waterfall and, showing only his profile like the Ancient of Days, directs his discourse toward the roaring stream while none can hear him yet all stand in awe, while the great man's flaming white mane blows in the wind (MM 611ff.).

Castorp is more bereft over Peeperkorn's death than over Madam Chauchat's impending and permanent departure. She even complains to Castorp that he takes too easily the loss of her love to Peeperkorn, and she is especially offended at the strong brotherhood of their friendship (MM 589). He kisses her compassionately on the forehead ( $M M$ 616), a clear sign that she no longer fascinates him. As Jung might say, the spark of vitality passes from one archetype to another, depending on the stage of one's advance into what was previously unconscious. But Peeperkorn's death and Clavdia's departure, in the aftermath of his snow vision, seems to suck all the meaning out of Castorp's existence. In Jung's terms, such eruptions of meaning from the unconscious into consciousness as Castorp has experienced in his beautiful-horrific vision in the snow and in the archetypal excesses of his relations to Madam Chauchat and Mynheer Peeperkorn come unbidden but leave behind the immense task of understanding and integrating them. The Dark Night of the Soul follows the apotheosis of divine presence, when the immense gap now evident between the impossible-to-sustain elevation and the apparent nothingness of mere human existence challenges one's resources.

To the young Castorp, in the section called "The Great Stupor," it seems as though uncanniness has overcome the world, as though an evil demon has consumed all meaning. Dr. Behrens worries about what he diagnoses as boredom. 
Castorp feels stupefied, experiencing a life without time, care, or hope-a stagnating hustle-bustle of depravity - as a living death. The occasion of his personal loss of soul is worsened through its synchronistic coincidence with the horror of the eerie and skewed state in which the outside world of Europe is entrapped. Castorp feels catastrophe in the air. The situation in Magic Mountain is thus reminiscent of Jung's dreams of rivers of blood occurring at precisely this time just before the outbreak of WWI, but which were not yet published. Settembrini earlier remarks to Castorp that life at the Berghof could be likened to a doomed luxury liner. Dr. Behrens seeks a medical reason, some infection, as an explanation, but Castorp intuits a horrible end. Critics like Vaget and Nehamas interpret this stage of emptiness as proof that Castorp really is, after all, only a very ordinary German who, once the exciting stimuli disappeared, loses contact with his merely apparent attainments. Nehamas, for example, writing of this section of the novel, finds it "impossible to resist" the suspicion that Castorp is no "different from the other [ordinary] characters" (116). I would advise such critics to read, at the very least, Jung's Symbols of Transformation, and then to reread more carefully Mann's masterful novel.

In Jung's study of alchemy, he regards such periods of darkness as the stage of putrefaction in which the collapse and disorientation of consciousness may last a considerable time. This stage demands great patience and courage $(C W 16$, par. 476). He quotes an alchemical text: "O blessed Nature, blessed are thy works, for that thou makest the imperfect to be perfect through the true putrefaction, which is dark and black. Afterwards thou makest new and multitudinous things to grow, causing with thy verdure the many colours to appear" ( $C W 16$, par. 479). Jung relates this to the nigedo in the writings of St. John of the Cross. He describes the dark radiance of God as piercing and purifying the soul ( $C W 16$, par. 479). Not everyone with so much to integrate manages to accomplish the task, but Castorp has a reliable intuition and a solid understanding. When Dr. Behrens purchases a large phonograph player with collections of music, Castorp sees an unexpected mode of recovery through music.

When other patients begin to mistreat the records, Castorp simply announces, just as Peeperkorn would have, that he is in charge of the records and will keep the keys. His personal presence silences all opposition. He has assimilated the primary characteristic of Peeperkorn just as he has from all his other mentors, including Clavdia Charchat. Castorp then masters and arranges the entire catalogue of records and begins focusing on certain operas that especially speak to him. Schopenhauer, one of Mann's major inspirations, describes music as unique among the arts because, unlike paintings that copy objective reality, which is already a copy of an idea in the cosmic energy of primal will, music expresses the primal will directly. Nietzsche interprets Schopenhauer's primal will, along with the spirit of music, as the Dionysian energy that provides the key to understanding Greek tragedy. This primal energy, given Apollonian form, explains the secret, according to Nietzsche, of the beautiful divine world on Mt. Olympus, the magic mountain from which Mann names his tragic novel. On the ancient Athenian tragic stage, the flood of terrible Dionysian energy that animates the conflicted hero behind his mask is converted into beautiful articulations through Apollo. In studiously listening to the sequence of operas that sing heroically and passionately of death and life, Castorp 


\section{Brown}

begins to retrieve from the depths his lost soul in this most important Nekyia of his life. It is no accident that the séance scene, a dramatized Nekyia, takes place during this period. But as opposed to the inauthentic and tawdry vision of his departed cousin with the hint of coming war, Castorp's true Nekyia is a significant and successful recovery, which restores him to his individuated being. As Heidegger makes clear, the experience of the Nothing, utter nothingness, the falling away of all meaning, forces the disengagement necessary to awaken the awareness of the essential truth of Being (Pathmarks 83). This is a modern restatement of the turn that Plato calls periagoge, the turning of the soul away from all that is transitory toward the blissful wholeness of truth, agathon (Republic 518a-e). Castorp's recovery, like Nietzsche's view of tragedy, is born from the spirit of music.

Whether Castorp accomplishes this recovery of his individuating soul, however, or whether he loses it permanently and falls back into everydayness remains a contentious topic among critics of the novel. For example, Vaget marshals voluminous citations to claim that, for the "ordinary" Hans Castorp, music is an opiate that causes him to relapse into his previous longing for death (123-138). But Scaff defends just as skillfully, also with abundant citations, the contrary conclusion that even Schubert's wanderer in the linden tree cycle overcomes the temptation of death and that, like him, Castorp is directed toward renewal (57). The ambiguity caused by Mann's constant incorporation of opposites, appropriate to psychic stress, makes possible one-sided arguments for either polarity, but with the help of Jung's insights into the ups and downs of individuation in a world of opposites, we can embrace the overarching wholeness of the novel in a way that allows us to incorporate Vaget's negative assessments as denoting the strength of temptation that Castorp overcomes in the direction that Shaff describes.

The musical form most significant for Castorp's recovery is Schubert's Die Winterreise, a cycle of twenty-four poems in which his favorite is Der Lindenbaum. In this poem a tree in deepest winter darkness seems to invite a wanderer to his death: "Come here old comrade, find your rest here." Was this back-sliding, Castorp asked himself? Not at all, he thinks, for nothing is healthier than to realize that the fresh, plump fruit of life is liable to rot and decay. The fruit of life is "sired by death and pregnant with death," yet the miracle of soul makes possible life's unscrupulous beauty. Despite its brevity, Castorp "affirmed life and loved its organic wholeness," and thereby "he triumphed over himself" (MM 643). Immersed in the song cycle, then, Castorp's triumph is the recovery of the resolve in favor of life that he made so poignantly during the snow episode. Those who see Castorp's transformation as a failure must have missed these lines. Precisely because of Castorp's success, the novel is tragic in keeping with the source of its title. The fruit of such advanced realization and the achievement of such an individuated life should be directed back to the social and historical community of human beings. As Jung writes, "Individuation does not shut one out from the world, but gathers the world to oneself" ("The Spirit of Psychology" 435). But the declaration of war hits the Berghof like a thunderclap. Instead of devoting his immense achievement to the demands of civilization, Castorp finds himself on the 
battlefield as the soldier his cousin never got to be. We depart from him as he runs across the battlefield singing the song of Schubert's that was worthy of dying for, a new word of love. In his openness to the frightening totality that is now his world, in what are probably his last moments, this timeless awareness that embraces all time, this glimpse of eternity in which life and death are inextricably linked, would be the capstone of any life.

Such is my reading, but the basic bifurcation of interpretations is most glaring precisely here. Nehamas, for example, writes of the "sluggish Hans Castorp": "Even if he did succeed, he probably did not succeed on a grand scale, as his unobtrusive departure and his undistinguished march through the battlefields of war suggest" (116). Capping this anti-climactic reading, Nehamas is willing to leave Castorp to his "no longer necessarily interesting fate." Vaget, having diagnosed the "rot, decay, and poison" of Der Lindenbaum (136) largely shares Nehamas' reading: the hero "stumbles toward his death in Flanders fields" (137). But Shaff, who argues that Castorp's "love for life is recovered from music" (59), aligns with Hermann J. Weigand's assessment that "Hans Castorp develops from a simple young man to a genius in the realm of experience" (25). Weigand views Castorp's experiential elevation on the battlefield as an "awareness of a mystic bond of unity between himself and the cosmos" (143).

Even without Jung, critics should not forget Mann's significant reference to Plato's Phaedrus in Death in Venice, to which Magic Mountain was originally a companion piece. There Mann describes the movement of Eros, first awakened by the beloved, as the way to the spirit, where thought merges wholly into feeling and feeling wholly into thought as the lover's and the artist's highest joy (45-46). Jung's archetypal stages, including setbacks, of the process toward spiritual wholeness, first detailed in Symbols of Transformation, redefine the rungs of this natural but elusive ladder of the spirit, which, if followed intelligently and mindfully, frees one from the ego's instinctual roots and the conflict of opposites, thereby liberating the self (Atman). Castorp overcomes even this last distinction in his transcendent unity with the cosmos as the completion of his spiritual crescendo. Joseph P. Lawrence writes, "It is Hans Castorp who (besides being the true genius) is the true 'child of peace.' He is kept pure" by refusing to see humanity and 'what is" as "polarized into good and evil" (11). Now that Hades has encompassed the world in the raging hell of battle, Castorp, drawing once again on his insight from the snow episode, an insight recovered through music after the "great stupor" of soul loss, "refuses to grant death dominion over his thoughts" (Lawrence 11).

Accordingly, Shaff describes the ending of Magic Mountain as a kairos: a fulfilling of time, a revelation, an event of "true knowledge" born at the moment "at which time is disturbed by eternity" (119). By portraying this meeting of time and eternity on the field of battle, where the sublime horror of the nihilistic will-topower offers the mock liberation of annihilation, and the only choice an awakened human being can make under the impending threat of death is to remain cheerfully open to the brevity of life's fullness, Mann demonstrates art's capacity to exceed the bounds of Jungian psychology. Jung's description of the human being is by comparison to this artistic unity merely piecemeal. He portrays the libido as a metonymy of the person, he describes images, dreams, and myths as roads to the unconscious, and he claims that the symbolic merger of conscious and unconscious 


\section{Brown}

will complete the path to the wholeness. As a picture of human experience, such descriptions remain fragmentary, schematic, theoretical, and, as Mann indirectly shows, even incomplete, something Jung himself seems reluctantly to admit to Shin'icni Hisamatsu (118). Nonetheless, Jung's insights provide a significant decoding of Castorp's progression through the novel from his fragmented normality at the beginning, into his series of personal and transpersonal trials, and eventually to his spiritual summit of cosmic acceptance of life and death perceived in the snow episode and enacted on the battlefield. As Lawrence expresses it, the Castorp who runs courageously across the battlefield amid shrapnel is no longer the same man who was once terrified at night by his own heartbeat or who at first lay down in the snow willing to die (11). His tragic transfiguration into the fullness of humanity is exemplary for those who can grasp its labyrinthine process.

\section{Works Cited}

Bacon, Francis. Advancement of Learning. Oxford: Oxford UP, 1974. Kindle Edition.

Beebe, John. "The Red Book as a Work of Conscience.” C. G. Jung Society of N. Texas. St. Thomas Episcopal Church, Dallas, Texas. 9 Sep. 2011. Address.

Berk, M. F. M. van den. The Magic Flute: An Alchemical Allegory. Leiden: Koninklijke, 2004. Print.

Bettelheim, Bruno. "A Secret Asymmetry.“ Freud's Vienna \& Other Essays. New York: Knopf, 1990. Print.

Brooke, Roger. Jung \& Phenomenology. Pittsburg: Trivium, 1991. Print.

Campbell, Joseph. Creative Mythology, Masks of God. Vol. 4. New York: Viking, 1968. Print.

---. Spirit and Nature: Papers from the Eranos Yearbooks. Ed. Joseph Campbell. Princeton: Princeton UP, 1954. Print.

Creuzer, Georg Friedrich. Symbolik und Mythologie der alten Völker, besondes der Griechen. Leipzig: Carl Wilhelm Leske, 1837. Hildesheim: Georg Olms, 1990. Print.

Freud, Sigmund. "Totem and Tabu." The Basic Writings of Sigmund Freud. Trans. Dr. A. A. Brill. New York: Random, 1938. Print.

Haule, John Ryan. “Analyzing From the Self," Pathways into the Jungian World. Ed. Roger Brooke. London: Routledge, 2009. Print.

Heidegger, Martin. Being and Time. Ed. and rev. Dennis Smith. Trans. Joan Stambaugh. Albany: State University of New York P, 2010. Print.

---. Being and Truth. Trans. Gregory Fried and Richard Polt. Bloomington: Indiana UP, 2010. Print.

---. The Concept of Time. Trans. Ingo Farin with Alex Skinner. New York: Continuum, 2011. Print.

---. The Essence of Truth. Trans. Ted Sadler. London: Continuum, 1998. Print.

---. Pathmarks. Trans. Thomas Sheehan, et al. Cambridge: Cambridge UP, 1998. Print.

Heracleitus of Ephesus. Ancilla to the Pre-Socratic Philosophers. Trans. Kathleen Freeman. Cambridge: Harvard UP, 1962. Print.

Hisamatsu, Shin'ichi. “A Dialogue Between Carl G. Jung and Shin'ichi Hisamatsu.” Self and Liberation: the Jung-Buddhism Dialogue. Ed. Daniel J. Meckel and Robert L. Moore. Mahwah, N. J.: Paulist, 1992. 100-118. Print.

Jung, C. G. Analytical Psychology: Notes of the Seminar Given in 1925. Ed. William McGuire. Bollingen Series 99, Princeton: Princeton UP, 1989.

---. The Collected Works of C. G. Jung. Ed. Sir Herbert Read et al. Trans. R. F. C. Hull. Bollingen Series 20. Princeton: Princeton UP, 1953-79. 20 vols. Print.

---. Memories, Dreams, Reflections. Ed. Aniela Jaffé. Trans. Richard and Clara Winston. New York: Random House, 1989. Print.

---. The Practice of Psychotherapy. CW 16. 1966. Print.

---. Psychology and Religion: West and East . CW 11, 1989. Print.

---. Psychology of the Unconscious. Trans. Beatrice M. Hinkle, M.D. New York: Moffat, 1916. Print. 
---. The Red Book: Liber Novus. Ed. Sonu Shamdasani. Trans. Mark Kuyburz. New York: PhilemonNorton, 2009. Print.

---. "The Spirit of Psychology." Spirit and Nature: Papers from the Eranos Yearbook. Ed. Joseph Campbell. Bollingen Series 30, Vol 1. Princeton UP, 1954. Print.

---. Structure and Dynamics of the Psyche. CW 8, 1969. Print.

---. Symbols of Transformation. CW 5, 1990. Print.

Kant, Immanuel. Critique of Pure Reason. Ed. and Trans. Paul Guyer and Allen W. Wood. Cambridge: Cambridge UP, 2000. Print.

Lawrence, Joseph P. "Transfiguration in Silence." A Companion to Thomas Mann's Magic Mountain. Ed. Stephen D. Dowden. Rochester: Camden, 2002. Print.

Mann, Thomas. Death in Venice And Seven Other Stories. Trans. H. T. Lowe-Porter. New York: Vantage, 1963. Print.

---. Magic Mountain. Trans. John E. Woods. New York: Alfred A. Knopf, 1996. Print.

Nehamas, Alexander. "Nietzsche in the Magic Mountain." Thomas Mann's The Magic Mountain. Ed. Harold Bloom. New York: Chelsea, 1986. Print.

Nietzsche, Friedrich. Birth of Tragedy. Ed. Raymond Geuss. Trans. Ronald Speirs. Cambridge: Cambridge UP, 1999. Print.

---. Unmodern Observations. Trans. William Arrowsmith, Gary Brown, and Herbert Golder. New Haven: Yale UP, 1991. Print.

---. "Wagner at Bayreuth." trans. Gary Brown. Unmodern Observations. Print.

Paracelsus. The Hermetic and Alchemical Writings of Paracelsus. Ed. and Trans. Arthur Edward Waite. Charleston: Forgotten Books, 2007. Print.

Scaff, Susan von Rohr. History, Myth, and Music: Thomas Mann's Timely Fiction. Columbia: Camden, 1998. Print.

Schiller, Friedrich. On the Aesthetic Education of Man in a Series of Letters. New York: Fredrick Ungar, 1965. Print.

Vaget, Hans Rudolf. "Politically Suspect.” Thomas Mann's The Magic Mountain. Ed. Hans Rudolf Vaget. Oxford: Oxford UP, 2008. Print.

Weigand, Hermann J. The Magic Mountain. Chapel Hill: U of North Carolina P, 1964. Print.

\section{Notes}

\footnotetext{
${ }^{1}$ Although the liberated Miss Miller was institutionalized briefly at the insistence of her family, she did not suffer a breakdown and was able to continue her successful journalistic and modeling career. Jung had feared his own breakdown since boyhood after learning of Friedrich Nietzsche's fate. Perhaps this fear drove his choice of psychiatry as a career and maybe even his pessimistic interpretation of Miss Miller.

${ }^{2}$ C. G. Jung, Symbols of Transformation. Friedrich Nietzsche, Unmodern Observations. Paracelsus, The Hermetic and Alchemical Writings of Paracelsus. Friedrich Schiller, Letters on the Aesthetic Education of Man.

${ }^{3}$ Martin Heidegger writes about Plato's myth of the cave in the following books: "Plato's Doctrine of the Truth" in Pathmarks 155-82, The Essence of Truth 17-65, and Being and Truth 101-36.
} 